\title{
Vliv říčního dřeva na morfologické a sedimentologické parametry koryta na př́kladu meandrujícího toku Odry
}

\author{
Effect of instream wood on channel morphology and sedimentology: an example of \\ the meandering Odra River
}

\section{Václav Gurkovský $\rightarrow$, Tomáš Galia}

Katedra fyzické geografie a geoekologie, Prírodovědecká fakulta, Ostravská univerzita, Chittussiho 10, 71000 Ostrava-Slezská Ostrava

\author{
Key words: \\ instream wood, channel morpholo- \\ gy, sediments, organic matter, the \\ Odra River \\ ॄ vaclav.gurkovsky@gmail.com \\ Editor: \\ Martin Ivanov
}

\begin{abstract}
Instream wood is a natural phenomenon that significantly influences a function of the fluvial system in forested river basins and represents a natural part of this system. However, the majority of these relatios between instream wood and fluvial ecosystems were investigated in mountain streams or gravel-bed rivers and we are lacking field data from lowland meandering rivers. This study deals with the complex assessment of instream wood on morphology and sediment parameters including the content of organic material at spatially detailed scale of the selected bend of the Odra River. Within the site of interest (66.5 river $\mathrm{km}$ ), 12 instream wood pieces were identified (lenght $\geq 1 \mathrm{~m}$, diameter $\geq 10 \mathrm{~cm}$ ). Their presence significantly affected river morphology, when they were the main initiator of pool formation. In total, 28 samples of surface bed sediments were collected from the thalweg, bars and lateral pool. In laboratory, samples were subjected to grain size analysis (sieving method) and loss on ignition (LOI) to obtain content of organic matter. The majority of bed sediment samples were coarse grained and these samples were located in the thalweg. The main component of these samples is gravel, often supplemented with admixtures of finer fractions. The analysis of data did not show the effect of instream wood on the deposition of organic matter in bed sediments. One of the reasons may be the presence of coarse grained material which generally contains a small amount of organic matter.
\end{abstract}

Úvod

Výsledky bezmála padesátiletého výzkumu zaměřeného na dřevní hmotu v říčních korytech nám poskytují základní informace o tom, jak se dřevo do vodního toku dostává (Piégay et al. 1999), jak je v něm transportováno (Curran 2010), jak může dřevo ovlivňovat hydrauliku (Curran, Wohl 2003), korytovou morfologii (Kail 2003; Magilligan et al. 2008), ale také sedimentologické parametry (Máčka, Krejčí 2010a; Osei et al. 2015), množství organické hmoty v sedimentech (Bilby, Ward 1991; Daniels 2006; Wohl, Scott 2017) či diverzitu organismů vázaných na vodní nebo břehové prostředí (Fausch, Northcote 1992). Ačkoli se můžeme opř́t o dostatek relevantních zdrojů, stále se objevují mezery především ve schopnosti kvantitativně předpovídat vzájemné působení mezi dřevní hmotou a směrem proudění, chodem sedimentů nebo vodní biotou (Wohl 2017). Vůbec nejvíce probíraným tématem je vliv říčního dřeva na morfologii vodních toků především v horském prostředí a jeho předpolí, podstatně méně popsaná je pak funkce tohoto prrírodního fenoménu v meandrujících tocích. Jak již bylo zmíněno, říční dřevo ovlivňuje širokou škálu parametrů a charakteristik vodního toku. Na základě dřívějších studií Greškové z let 2005 a 2007, rozdělili 
Máčka a Krejčí (2010b) ovlivněné aspekty do čtyř hlavních kategorií: a) hydraulika a hydrologie, kde říční dřevo vytvárí nerovnosti a funguje jako drsnostní prvek v korytě, klade odpor a ovlivňuje směr proudění; b) morfologie, kdy říční dřevo ovlivňuje rychlost a intenzitu hloubkové a břehové eroze, má vliv na stabilitu břehů a na tvar prríčného i podélného profilu, iniciuje tvorbu výmolů a náplavů; c) látkově-materiální bilance, kde v tomto smyslu říční dřevo zpomaluje chod dnových splavenin, zachytává drobný organický materiál a uvolňuje živiny; d) biologie, kdy díky říčnímu dřevu je zvýšená pestrost vodních biotopů a také druhová diverzita vodních organismů, říční dřevo vytváří proudové stíny a refugia pro ryby. $\mathrm{V}$ tocích $s$ nižším sklonem může dřevo snížit nebo zvýšit stabilitu říčních břehů, nebo dát impuls k vzniku centrálních lavic a krátkých divočících úseků. Dřevo ve vodním toku může taktéž způsobit vznik povodňových koryt či vyvolat odškrcení meandru (Máčka, Krejčí 2010a).

Cílem této studie je komplexně zhodnotit vliv ř́čního dřeva na morfologii a parametry sedimentů, včetně obsahu organické hmoty, v jednom ze zákrutů řeky Odry. Výskyt říčního dřeva obecně zvyšuje heterogenitu prostředí, avšak tato problematika nebyla dosud uspokojivě ověřena na úrovni nížinných meandrujících toků. Předpokládali jsme, že stejně jako u koryt s vyšším gradientem bude mít říční dřevo vliv na jeho morfologické a sedimentologické parametry. Dále jsme chtěli ověřit, že v místech výskytu říčního dřeva budou pozorovány hodnoty s vyšším obsahem hrubé a jemné partikulované organické hmoty, což bylo dřive deklarováno v prrípadě nížinného meandrujícího toku o malé ploše povodí $~ 50 \mathrm{~km}^{2}$ (Daniels 2006) a rovněž nížinného potoka s variabilním podílem štěrkové frakce (Osei et al. 2015).

\section{Zájmový říční úsek}

Zkoumaný úsek řeky Odry se nachází na katastrálním území obce Suchdol nad Odrou v Moravskoslezském kraji. Jde o meandrující úsek na říčním km 66,5 (GPS koordináty: N 49,64568 E 17,95851) (obr. 1) s příspěvkovou plochou povodí $587 \mathrm{~km}^{2}$. Úsek se nachází uvnitř $\mathrm{CHKO}$ Poodři a spadá pod správu Povodí Odry. Průměrný dlouhodobý průtok na stanici Bartošovice (říční km 50,4) je $6,75 \mathrm{~m}^{3} / \mathrm{s}$. Z geologického hlediska leží studovaná lokalita na rozhraní dvou primárních geologických celků ČR a to Českého masivu a Vnějších Západních Karpat. Fundament tohoto území je terciérního založení, nicméně povrch je překryt kvartérními sedimenty (sprašové hlíny, glacifluviální a fluviální sedimenty). Na některých místech se vyskytují také glacigenní a glacilakustrinní sedimenty (Czudek 2001). Geomorgologicky náleží studovaný úsek do oblasti Západních Vněkarpatských sníženin, celku Moravské brány a podcelku Oderské brány (Demek, Mackovčin 2006). Dominantním morfologickým tvarem je samotné kory to řeky Odry, které si i přes lokální úpravy (obvykle pouze v blízkosti mostů) zachovalo charakter přirozeného nížinného toku. Točivost přilehlého úseku ke zkoumané lokalitě lze charakterizovat poměrně vysokou sinusoitou 1,9 odpovídající dobře vyvinutému meandrujícímu říčnímu vzoru. Ve sledovaném úseku se aktivní meandrování projevuje tvorbou břehových nátrží $\mathrm{v}$ nekonsolidovaných sedimentech nárazových břehů spojených s dodávkou rríčního dřeva do toku. Šířka plného koryta se pohybuje v rozmezí 10-20 metrů v závislosti na poloze přičného profilu, kdy nižší hodnoty šírky jsou vázány především na přímé úseky mezi jednotlivými meandry. Hloubka plného koryta je opět značně variabilní vzhledem k výskytu relativně pravidelné sekvence brodů a tůní, kdy v rámci tůní může dosahovat až 3-4 metrů.

\section{Metody}

Terénní práce probíhaly ve dvou etapách, v červenci a říjnu roku 2017. V období mezi těmito měsíci nebyly zaznamenány žádné zvýšené průtoky, které by ovlivnily korytovou morfologii. Prvním krokem bylo geodetické zaměření lokality pomocí totální stanice Topcon GTS-233N. Zaměřena byla morfologie koryta a poloha jednotlivých kusů říčního dřeva. Byly zaznamenávány pouze velké kusy dřevní hmoty o délce $\geq 1 \mathrm{~m}$ a průměru kmene $\geq 10 \mathrm{~cm}$ (tzv. $L W$, z angl. large wood). U říčního dřeva byly zaznamenány jeho následující parametry: délka, tloušt ka na jeho obou koncích a přítomnost kořenového balu. Délka byla měřena s použitím svinovacího metru s přesností

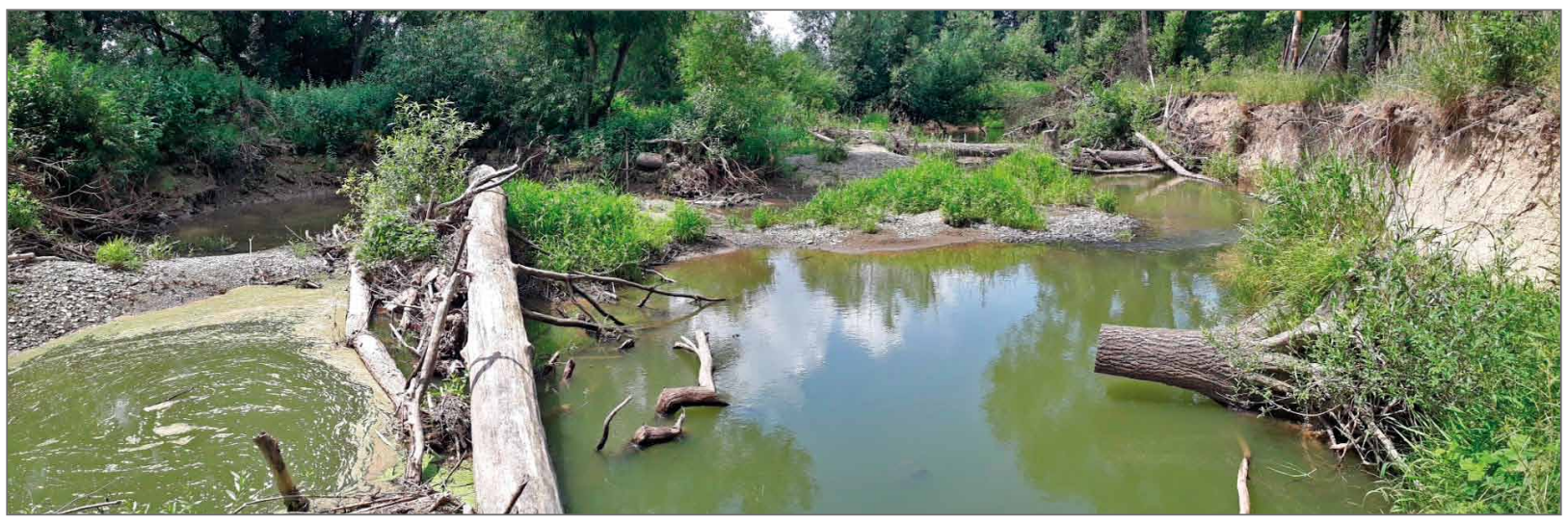

Obr. 1: Panoramatický snímek zájmové oblasti (v levé části snímku lze vidět zmiňovanou boční tůň, v pravé části např́iklad vývrat po viditelném antropogenním zásahu).

Fig. 1: Panoramic view of the area of interest (in the left part of photo a lateral pool is located, in the right part for example a wood is present with visible anthropogenic intervention). 
$\pm 10 \mathrm{~cm}$, šírka s přesností $\pm 1 \mathrm{~cm}$. Přesnost měření byla ovlivněna především polohou říčního dřeva, některé kusy byly jedním koncem ponořeny ve vodě nebo zasedimetovány, nicméně byla snaha měřit s co největší přesností. Následujícím krokem v terénu byl odběr korytových sedimentů. Vzorky byly odebírány $\mathrm{z}$ různých míst $\mathrm{v}$ rámci celého koryta $s$ přítomnosti i nepř́ítomnosti struktur říčního dřeva. Pozice odběrů byly taktéž zaměřeny totální stanicí.

$\mathrm{Z}$ bodové sítě získané geodetickým měřením (hustota 0,4 bodů na $1 \mathrm{~m}^{2}$ ) byl v programu ArcGIS vytvořen hrubý výškový model říčního dna a břehů pomocí prostorové interpolace metodou „topo to raster" s velikostí buňky $0,1 \mathrm{~m}$. Aby byly

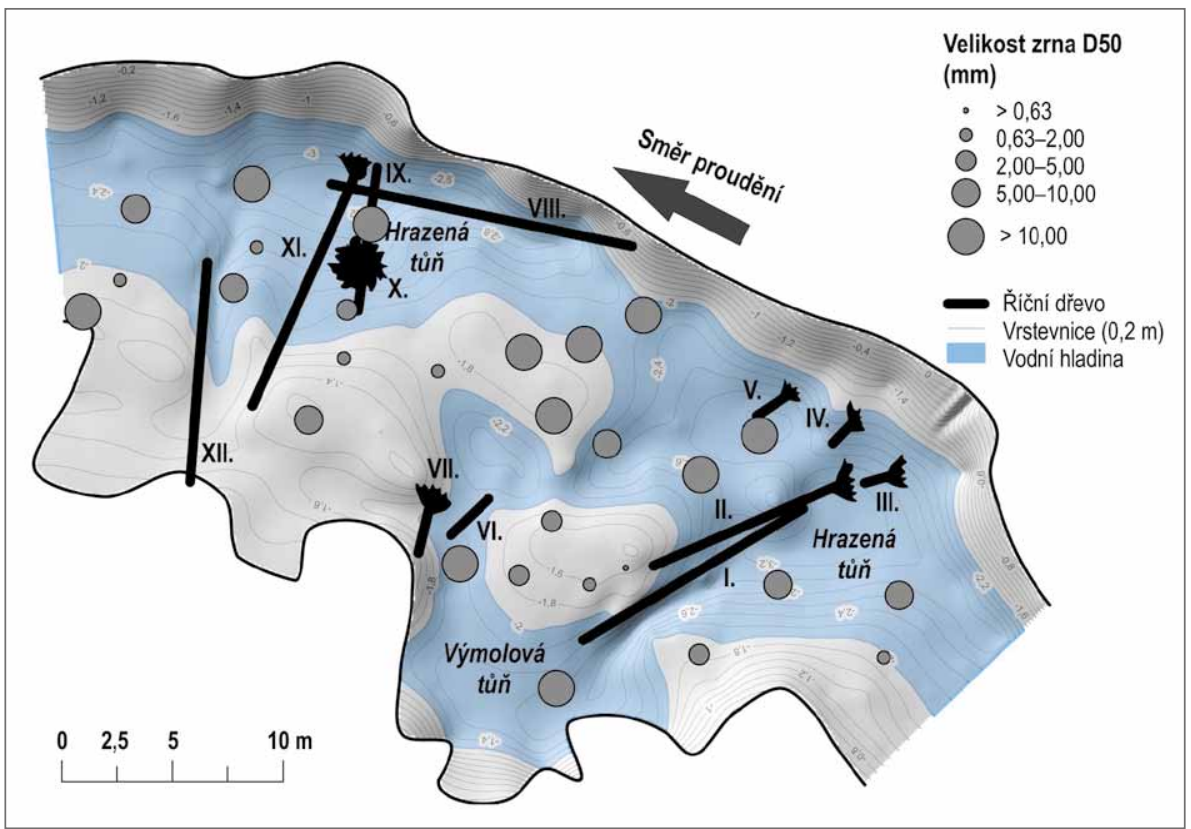

Obr. 2: Vizualizace znázorňující prostorové rozložení D50 (zrnitost říčních sedimentů) v zájmové oblasti, poznámka: (vodní hladina při $\mathrm{Q}=0,7 \mathrm{~m}^{3} / \mathrm{s}$, arabská čísla označují identifikátory vzorků, římská čísla identifikátory jednotlivých kusů říčního dřeva).

Fig. 2: Visualization showing spatial distribution D50 (granularity of sedimentary grains) in the area of interest, note: (water level at $\mathrm{Q}=0.7 \mathrm{~m}^{3} / \mathrm{s}$, the arabic numbers indicate sample ID, the roman numbers indciate instream wood ID). tyto biologické struktury v mapových výstupech lépe identifikovatelné, byly jejich symbolické náčrtky dotvořeny v programu Inkscape. Z naměřených parametrů říčního dřeva byl vypočítán jeho objem. Tento výpočet probíhá aproximací kusu říčního dřeva na objekt komolého kuželu, podle vztahu: $V=1 / 3 \pi h\left(R^{2}+R^{*} r+r^{2}\right)$, kde $h$ značí výšku, $R$ poloměr spodní podstavy, $r$ poloměr horní podstavy.

V laboratoři granulometrie a sedimentologie na KFG OSU byly odebrané korytové sedimenty podrobeny postupně procesu sušení, sítování a žíhání. Granulometrická analýza proběhla na granulometrické sestavě FRITSCH, kde byly vzorky podrobeny mokrému (doba prosevu 7 minut, amplituda rozkyvu $2 \mathrm{~mm}$ ) a následně i suchému sítování (doba prosevu 1 minuta, amplituda rozkyvu $1 \mathrm{~mm}$ ). U analyzovaných sedimentů byl v programu Gradistat (Blott, Pye 2001) vypočítán koeficient vytřídění $[\sigma \mathrm{I}]$ a průměrná velikost zrna $\left[\mathrm{M}_{\mathrm{z}}\right]$ (Folk, Ward 1957) v jednotkách phi $[\Phi]$. Pro koeficient vytř́ídění uvádíme rovněž šestistupňovou kvalitativní stupnici dle Folka a Warda (1957). Dalším sledovaným parametrem analyzovaných sedimentů bylo stanovení množství organické hmoty. Procentuální obsah organické hmoty ve vzorku se vypočte podle vztahu $m=\left(\left(m_{1}-m_{2}\right) / m_{1}\right) * 100$, kde $m_{1}$ odpovídá hmotnosti před žíháním a $m_{2}$ hmotnosti po žíhání. Vzorky byly při žíhání vystaveny teplotě $550^{\circ} \mathrm{C}$. Byla provedena korelace mezi průměrnou velikostí zrna $\mathrm{M}_{\mathrm{z}}$ a množstvím organické hmoty. Vzhledem k odlehlosti hodnot byl použit Spearmanův korelační koeficient, který představuje neparametrickou metodu, která při výpočtu využívá pořadí sledovaných veličin a nevyžaduje tedy normalitu dat.

\section{Výsledky}

V zájmové oblasti bylo identifikováno 12 kusů říčního dřeva (viz římská čísla I-XII na obrázku 2). Př́ítomné byly jak celé vyvrácené kmeny (I, II, VIII, XI a XII), tak i pařezy po viditelném úřezu motorovou pilou, kořenový bal byl ovšem zachován (III, IV, V, VII a X). Topografie dna prokazuje, že říční dřevo výrazně ovlivňuje jeho morfologii. Říční dřevo se zachovaným kořenovým balem (II, III, X a XI) lze v zájmové lokalitě považovat za iniciátory tvorby dvou hrazených tůní. Jako velmi výrazný drsnostní prvek se ukázaly být vývraty dvou kusů říčního dřeva nacházející se nejvýše po proudu (I a II). Tyto vývraty způsobily pro proud vodního toku překážku, což zapříčinilo vychýlení proudnice a vytvoření výmolové boční tůně (obr. 2). Ta je však průtočná pouze za vyšších vodních stavů. Všechny tyto tři tůně tvořily cca $50 \%$ plochu aktivního koryta studovaného úseku, což poukazuje na jasný vliv dřevní hmoty na tvorbu zón pomalého proudění v předmětném úseku. $V$ boční tůni byly lokalizovány také dva kusy říčního dřeva, $\mathrm{z}$ nichž jeden měl zachovaný kořenový bal (VI a VII). Vzhledem k jeho poloze a částečnému překrytí povodňovým materiálem se lze domnívat, že jde o alochtonní kus a byl tedy připlaven řekou $\mathrm{z}$ výše položených míst $\mathrm{v}$ povodí.

Průměrná velikost zrna, stupeň vytř́íění a popis vytř́ídění jsou uvedeny v tabulce 1 . Průměrná zrnitost $\left[\mathrm{M}_{\mathrm{z}}\right]$ odebraných vzorků se pohybovala od -3,446 do 5,034 $\Phi$ (0,03-10,9 mm; hrubý prach až středně hrubý štěrk). Hlavní složkou vzorků je štěrk, ve velké většině doplněn o příměsi jemných frakcí (kal). Dalším sledovaným parametrem u jednotlivých vzorků byl stupeň vytřídění

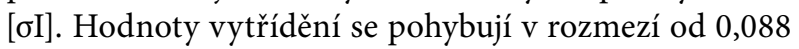


Tab. 1: Základní sedimentologické charakteristiky odebraných korytových sedimentů a informace o obsahu organické hmoty ( $\sigma \mathrm{I}$ - vytřríděnost, $\mathrm{M}_{\mathrm{z}}$ - průměrná velikost zrna). Tab. 1: Basic sedimentological characteristics of sampled bed sediments and information on organic matter content ( $\sigma \mathrm{I}$ - sorting, $\mathrm{M}_{\mathrm{z}}-$ mean grain size).

\begin{tabular}{|c|c|c|c|c|}
\hline $\begin{array}{c}\text { Označení } \\
\text { vzorku v mapě }\end{array}$ & $\begin{array}{l}\text { Průměrná velikost } \\
\text { zrna } M_{z}[\Phi]\end{array}$ & Vytříděnost $\sigma \mathrm{I}$ & $\begin{array}{c}\text { Popis } \\
\text { vytříděnosti }\end{array}$ & $\begin{array}{c}\text { Obsah organické } \\
\text { hmoty [\%] }\end{array}$ \\
\hline 1 & $-1,29$ & 2,76 & špatně & 0,43 \\
\hline 2 & 2,17 & 4,08 & velmi špatně & 0,42 \\
\hline 3 & $-1,19$ & 2,35 & špatně & 0,42 \\
\hline 4 & $-1,23$ & 2,42 & špatně & 0,34 \\
\hline 5 & $-1,65$ & 2,18 & špatně & 0,44 \\
\hline 6 & $-2,24$ & 2,03 & špatně & 0,39 \\
\hline 7 & $-2,55$ & 1,61 & slabě & 0,37 \\
\hline 8 & $-2,96$ & 1,02 & slabě & 0,52 \\
\hline 9 & $-0,09$ & 0,82 & středně & 0,48 \\
\hline 10 & $-2,21$ & 1,61 & slabě & 0,39 \\
\hline 11 & $-0,59$ & 2,65 & špatně & 0,41 \\
\hline 12 & $-1,93$ & 2,09 & špatně & 0,37 \\
\hline 13 & 0,38 & 1,77 & slabě & 1,45 \\
\hline 14 & $-2,58$ & 1,57 & slabě & 0,41 \\
\hline 15 & 5,03 & 5,07 & velmi špatně & 0,97 \\
\hline 16 & $-2,07$ & 2,39 & špatně & 0,29 \\
\hline 17 & $-1,14$ & 4,10 & velmi špatně & 1,03 \\
\hline 18 & $-2,15$ & 2,03 & špatně & 0,34 \\
\hline 19 & $-0,82$ & 4,09 & velmi špatně & 0,48 \\
\hline 20 & $-0,58$ & 1,67 & slabě & 1,83 \\
\hline 21 & $-2,15$ & 2,65 & špatně & 0,51 \\
\hline 22 & $-2,85$ & 1,56 & slabě & 0,49 \\
\hline 23 & $-3,45$ & 0,09 & velmi dobře & 0,44 \\
\hline 24 & $-2,84$ & 2,39 & špatně & 0,47 \\
\hline 25 & $-1,31$ & 2,81 & špatně & 0,44 \\
\hline 26 & $-2,18$ & 1,78 & slabě & 0,4 \\
\hline 27 & $-1,4$ & 3,79 & špatně & 0,46 \\
\hline 28 & $-0,23$ & 3,56 & špatně & 0,45 \\
\hline
\end{tabular}

do 5,071. Převažují sedimenty špatně a velmi špatně vytř́íděné (18 vzorků) nad sedimenty slabě a středně vytříděnými ( 9 vzorků). Z odebraných 28 vzorků byl pouze jeden klasifikován jako velmi dobře vytř́iěný (vzorek č. 23, $\sigma \mathrm{I}=0,088$ ). Tento vzorek je zároveň nejhrubším vzorkem a nacházel se $\mathrm{v}$ peřejnatém úseku vodního toku, kde došlo k zúžení průtočného profilu. Pro zjednodušení prostorové vizualizace byly stanoveny velikostní třídy, dle kterých byly definovány mediány zrnitosti (D50) pro jednotlivé vzorky. $Z$ této vizualizace (obr. 2) vyplývá, že odebrané vzorky sedimentů byly převážně hrubozrnného rázu. Z prostého porovnání hodnot D50 vyplývá, že hrubozrnnější frakce byly ukládány převážně v proudnici vodního toku a na přilehlých akumulačních formách, které bývají za vyššího vodního stavu pod hladinou. Podstatně jemnější sedimenty byly uloženy ve vyšších polohách akumulačních forem, hlavně na ostrůvku za prvními vývraty říčního dřeva (I a II).

$\mathrm{V}$ odebraných korytových sedimentech se množství organické hmoty pohybovalo v rozmezí 0,29-1,83\%. Rozdělení četností vzorků podle obsahu organické hmoty vystihuje histogram (obr. 3a) z kterého vyplývá, že vyjma čtyř vzorků jsou hodnoty obsahu organické hmoty velmi obdobné. U vzorků s vysokou hodnotou (tj. vzorky 13, 15, 17 a 20, viz obr. 3b) mohl být součástí žíhaného materiálu organický opad (např. zbytky listů z okolních porostů) rozkládající se v boční tůni. Zajímavostí však je, že vzorek s vůbec nejnižším obsahem organické hmoty pochází také právě $\mathrm{z}$ boční tůně. Nicméně v rámci tůně jde o stále velmi malý rozdíl (0,74\%). $\mathrm{Na}$ závěr byla hledána potenciální korelace mezi zrnitostí $\left[\mathrm{M}_{z}\right]$ a množstvím organické hmoty. Výsledná hodnota koeficientu $r_{s p}=0,30$ značí střední závislost, ovšem korelace není signifikantní ( $\mathrm{p}=0,125)$.

\section{Diskuze a závěr}

Ze studia účinků říčního dřeva v zájmové oblasti vyplývá několik základních poznatků. Ríční dřevo má zřetelný vliv na korytovou morfologii v zájmové oblasti. Jedná se především o erozní vliv, který se projevuje vznikem tůní pod vývraty jednotlivých kmenů v korytě, podobný efekt prezentuje i Kail (2003). Ten připisuje vznik tůně už jedinému padlému kmenu. Dalším sledovaným jevem byl vznik boční tůně, v důsledku vychýlení proudnice vodního toku. Pokud zmiňujeme erozní vliv říčního dřeva, je na místě prezentovat také

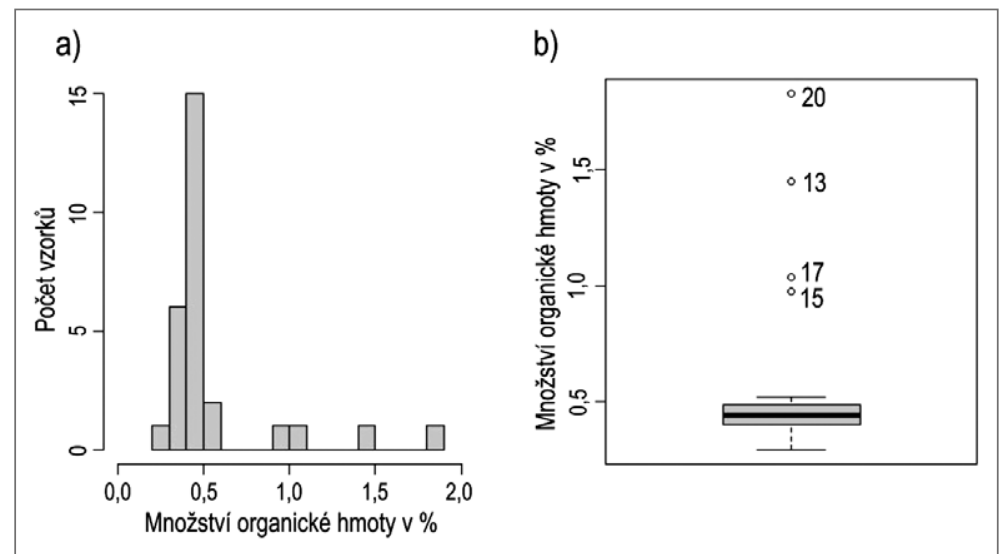

Obr. 3: Rozložení četností vzorků podle množství organické hmoty ve formě a) histogramu, b) krabicového grafu, poznámka: (v krabicovém grafu jsou uvedeny všechny vzorky, odlehlé hodnoty představují vzorky s vyšším obsahem organického materiálu).

Fig. 3: Distribution of sample frequencies according to the amount of organic matter in the form of a) histogram, b) boxplot, note: (all samples are shown in a boxplot, outliers are samples with higher organic material content). 
myšlenku o protierozním vlivu. Ta tkví v protektivní funkci kmenu VIII, který se nachází u nárazového břehu a svou polohou tak může oddálit erozi konkávního břehu. Z obrázku 2 vyplývá, že nebyl prokázán jasný vztah mezi výskytem ř́čćního dřeva a zrnitostí sedimentů, kdy i v tůních predisponovaných říčním dřevem se nacházel poměrně hrubý sediment. Je však možno se domnívat, že za kusy říčního dřeva I a II dochází $\mathrm{k}$ tvorbě proudového stínu za vyšších průtoků, což může podporovat sedimentaci jemnějších frakcí na ostrůvku mezi boční tůní a těmito kusy dřeva.

Očekávali jsme, že se nám povede formulovat závěr ohledně vztahu mezi průměrnou velikostí zrna a obsahem organické hmoty. Mezi těmito hodnotami sice byla sledována střední závislost, nicméně výsledek korelace není statisticky průkazný. Důvodem může být téměř homogenní obsah organického materiálu v sedimentech. Říční dřevo je označováno jako důležitý prvek při zadržování organické hmoty v korytových sedimentech (Bilby, Ward 1991; Daniels 2006; Wohl, Scott 2017). V meandrujícím toku s menšími rozměry koryta $(9 \mathrm{~m}$ šírka a $1,5 \mathrm{~m}$ hloubka plného koryta) se nejvyšší hodnoty obsahu organické hmoty (až do $30 \%$ podílu objemu na celkovém objemu sedimentů) vyskytovaly v těsné blízkosti struktur říčního dřeva a po jejich odstranění byl zaznamenán rapidní pokles retence organické partikulované hmoty v korytě (Daniels 2006). V naší zájmové lokalitě se přímý vztah mezi retencí partikulované organické hmoty a výskytem řičního dřeva nepodařilo vysledovat, jelikož hodnoty obsahu organické hmoty byly variabilní napříč celým korytem. Jednalo se tak o lokální odchylky, kdy při odběru a následném žíhání mohli být součástí vzorku např̀. zbytky listového opadu nebo jiný úlomek vegetace. Jedním z faktorů ovlivňující variabilitu těchto hodnot může být doba, po jakou je ř́iční dřevo činné v korytě, tedy v jaké fázi rozkladu se dřevo nachází a po jakou dobu je v toku stabilním prvkem. Zde se domníváme (na základě studia archivních ortofoto snímků od ČÚZK), že se stromy vyvrátily do koryta během povodňové události $\mathrm{v}$ roce 2010. V druhém př́ípadě může hrát roli zrnitost substrátu. V lokalitě se nachází převážně hrubozrnný substrát, což nepředstavuje ideální matrici k zachycení partikulované organické hmoty vzhledem $\mathrm{k}$ aerobnímu prostředí. Tuto druhou hypotézu podporují předchozí výzkumy vlivu nápěchů rríčního dřeva na ukládání partikulované organické hmoty v závislosti na zrnitosti korytových sedimentů, kdy byl zjištěn signifikantně nižší obsah organické hmoty u úseku nížinného potoka s převažujícím štěrkovým substrátem $\mathrm{v}$ porovnání $\mathrm{s}$ úseky $\mathrm{s}$ dominantními jemnějšími frakcemi (Osei et al. 2015).

\section{Poděkování}

Autoři děkují recenzentům Pavlu Roštínskému a Zdeňku Máčkovi za jejich cenné pripomínky, které pomohly zkvalitnit výsledný text. Studie byla podpořena interním grantem Ostravské univerzity (SGS02/PřF/2019-2020). 


\section{Literatura}

Bilby, R. E., Ward, J. W. (1991). Characteristics and function of large woody debris in streams draining old-growth, clear-cut, and second-growth forests in Southwestern Washington. - Canadian Journal of Fisheries and Aquatic Sciences, 48, $2499-2508$. https://doi.org/10.1139/f91-291

Blott, S. J., Pye, K. (2001). GRADISTAT: a grain size distribution and statistics package for the analysis of unconsolidated sediments. - Earth Surface Processes and Landforms, 26, 1237-1248.

Curran, J. H., Wohl, E. E. (2003). Large woody debris and flow resistance in step-pool channels, Cascade Range, Washington. Geomorphology, 1-3, 51, 141-157. https://doi.org/10.1016/S0169-555X(02)00333-1

Curran, J. C. (2010). Mobility of large woody debris (LWD) jams in a low gradient channel. - Geomorphology, 116, 320-329. https://doi.org/10.1016/j.geomorph.2009.11.027

Czudek, T. (2001). Geomorfologický vývoj Oderské brány a Vítkovské vrchoviny. - In: Prášek, J. (ed.): Současný stav geomorfologických výzkumů. Sborník referátů z mezinárodního semináře konaného ve dnech 5.-7. dubna 2001. v Kružberku. Ostrava: Ostravská univerzita v Ostravě. 141 s. ISBN 80-7042-801-5

Daniels, M. D. (2006). Distribution and dynamics of large woody debris and organic matter in a low-energy meandering stream. - Geomorphology, 3-4, 77, 286-298. https://doi.org/10.1016/j.geomorph.2006.01.011

Demek, J., Mackovčin, P. (2006). Zeměpisný lexikon ČR: Hory a nížiny. Brno: Agentura ochrany př́rody a krajiny ČR, $582 \mathrm{~s}$.

Fausch, K. D., Northcote, T. G. (1992). Large Woody Debris and Salmonid Habitat in a Small Coastal British Columbia Stream. - Canadian Journal of Fisheries and Aquatic Sciences, 4, 49, 682-693. https://doi.org/10.1139/f92-077

Folk, R. L., Ward, W. C. (1957). Brazos river bar significance grain size parameters. - Journal of Sedimentary Petrology, 27, 3-26. https://doi.org/10.1306/74D70646-2B21-11D7-8648000102C1865D

Grešková, A. (2005). Zvyšky dreva v korytách riek: interakcie s korytovou morfológiou a fluviálnymi procesmi. - Geomorfológia Slovaca, 5, 1, 21-33.

Grešková, A. (2007). Využitie akumulácií zvyškov dreva (Large Woody Debris) při revitalizácii riečnych korýt. - In: Herber, V.: Fyzickogeografický sborník. Masarykova univerzita, Brno, 105-110.

Kail, J. (2003). Influence of large woody debris on the morphology of six central European streams. - Geomorphology, 51, $207-223$. https://doi.org/10.1016/S0169-555X(02)00337-9

Máčka, Z., Krejčí, L. (2010a). Morfologické a sedimentologické účinky říčního dřeva v korytě Černé Opavy. - Geologické výzkumy na Moravě a ve Slezsku, 17, 69-75.

Máčka, Z., Krejčí, L. (2010b). Výskyt dřevní hmoty v korytech vodních toků České republiky. - Vodní hospodářství, 2, 60, 33-35.

Magilligan, F. J., Nislow, K. H., Fisher, G. B., Wright, J., Mackey, G., Laser, M. (2008). The geomorphic function and characteristics of large woody debris in low gradient rivers, coastal Maine, USA. - Geomorphology, 3-4, 97, 467-482. https://doi. org/10.1016/j.geomorph.2007.08.016

Osei, N. A., Gurnell, A. M., Harvey, G. L. (2015). The role of large wood in retaining fine sediment, organic matter and plant propagules in a small, single-thread forest river. - Geomorphology, 235, 77-87. https://doi.org/10.1016/j.geomorph.2015.01.031

Piégay, H., Thévenet, A., Citterio, A. (1999). Input, storage and distribution of large woody debris along a mountain river continuum, the Drôme River, France. - CATENA, 1, 35, 19-39.

Wohl, E. (2017). Bridging the gaps: An overview of wood across time and space in diverse rivers. - Geomorphology, 279, 3-26. https://doi.org/10.1016/j.geomorph.2016.04.014

Wohl, E., Scott, D. N. (2017). Wood and sediment storage and dynamics in river corridors. - Earth Surface Processes and Landforms, 42, 5-23. 